\title{
U rogenital Complications among Girls with Genital Mutilation: A Hospital-Based Study in Khartoum
}

L ars A Imroth ${ }^{1}$, H ibba Bedri2, Susan E I M usharafi,2, A lia Satti², Tayseer Idris², M SIR K $\mathrm{H}$ ashim² $^{2}$ G aafar I Suliman², and Staffan Bergström

\section{Abstract}

To explore paediatric complications of female genital mutilation (FG M), 255 consecutive girls aged 4-9 years presenting to an emergency ward in Sudan were included in this clinical study. Full examination, including inspection of genitalia, was performed. Dipsticks for nitrite and leucocytes were used to diagnose suspected urinary tract infection (UTI). G irls with a form of FG M narrowing vulva had significantly more UTI than others, and among girls below the age of seven there was a significant association between F GM and UTI. 0 nly $8 \%$ of girls diagnosed as having UTI reported urogenital symptoms. In spite of the fact that $73 \%$ of the girls subjected to FGM were reported to have been bedridden for one week or more after the operation, only $10 \%$ stated immediate complications. We conclude that FG M contributes significantly to morbidity among girls, alarge share of which does not come to medical attention. (A fr J Reprod H ealth 2005; 9[2]: 118-124)

\section{RÉ SUMÉ}

A fin d'explorer les complications de la mutilation génitale féminine (M G F), nous avons inclu dans cette étude clinique les filles consécutives âgées de 4 à 9 ans qui viennent au service des urgences au Soudan. $0 \mathrm{n}$ a fait passer un examen compréhensif y compris l'inspection des organes génitaux. Le diagnositic de la suspicion del'infection urinaire (IU) a été fait à l'aide de la jauge pour les nitrites et les leucocytes. Les filles qui avaient une sorte de vulve qui a été pincé par la M G F avaient beaucoup plus de IU que les autres. Parmi les filles âgées de moins de sept ans, il y avait un lien important entre M G F et IU. II n'y avait que $8 \%$ des filles qui avaient les symptômes del'infection urogénitale. Malgré le fait que $73 \%$ des filles qui avaient la M G F ont été alitées pendant une semaine ou plus après I'opération chirurgicale, seules $10 \%$ avaient affirmé des complications immédiates. N ous concluons que la MG F contribue de manière importanteà la morbiditéchez les filles et qu'une grande majoritédes cas neviennent pas à I'hôpital. (Rev A fr Santé Reprod 2005; 9[2]: 118-124)

KEY WORDS: U rogenital, morbidity, FGM, UTI, Sudan

${ }^{1} \mathrm{D}$ ivision of International $\mathrm{H}$ ealth, Karolinsk a Institutet, Stock holm, Sweden. ${ }^{2} \mathrm{C}$ hildren's E mergency H ospital, Khartoum, Sudan

Correspondence: L ars A Imroth IH CA R, D ivision of International H ealth, Karolinsk a Institutet, SE -17176

Stock holm, Sweden. E -mail: L .A Imroth@ telia.com; Tel: +46705495195; F ax: +468311590 


\section{Introduction}

An estimated two million girls undergo female genital mutilation (FGM) every year. M ore than 130 million currently living girls and women have experienced the mutilating operation. They live mainly in north-east A frica, but FG $M$ is common in a belt reaching from east to west $A$ frica. ${ }^{1}$ Sudan is one of the countries where the practice of FGM is widespread. A bout $90 \%$ of women in northern Sudan have undergone genital mutilation. ${ }^{2,3} \mathrm{FG} \mathrm{M}$ is not only a problem in A frica, however. It has been described as being practised in southern parts of the A rabian peninsula, ${ }^{1}$ in M alaysia ${ }^{4,5}$ and Indonesia. ${ }^{6}$ Large immigrant groups from areas where FGM is prevalent are now present in Europe, N orth A merica and A ustralia. ${ }^{1}$

A WH O classification ${ }^{7}$ recognises four types of FGM : (i) excision of part or the entire clitoris; (ii) excision of the clitoris with partial or total excision of the labia minora; (iii) infibulation. Parts or all of the external genitalia (the clitoris, labia minora with or without the inner surfaces of labia majora) are excised. The raw surfaces of the labia are brought together by sutures, or traditionally by thorns, and legs are tied together; (iv) other mutilating practices affect the female genitalia, such as scraping, burning or piercing.

Complications of FGM have not been well elucidated in research. Few studies have been appropriately designed to measure the health effects. ${ }^{8,9} \mathrm{~F}$ indings about complications have been based on self-reported problems by adult women, case reports or theoretical assumptions. To our knowledge, there are very few clinical studies or other systematic research on the primary victim of the practice - the girl-child. O ne can argue over the necessity to conduct research on the complications of harmful practices like FGM. A fter all, the overall aim is to abolish FGM, and we already know that it causes pain and possibly other serious complications. It is, however, often neglected in the debate that this ancient tradition also carries positive values for those practising it. We believe further research is important to bet- ter understand the practice and to use correct arguments in campaigns against it, avoiding dissonance between people's live experiences and claims pronounced by eradication campaigns. M ost of those who oppose the practice in Sudan use medical complications as arguments. ,, $10-14^{-10}$ Research findings would also make it possible to improve health care for girls and women facing complications of FGM.

This paper was, therefore, written to confirm or reject two hypotheses: firstly, that FGM has significant immediate adverse health effects on the girl-child and, secondly, that FGM is significantly associated with urinary tract infections in girls.

\section{M ethods}

\section{Patients}

The research team worked daytime in theemergency ward of the Children's E mergency H ospital, $\mathrm{K}$ hartoum, on selected days from $\mathrm{M}$ arch to $\mathrm{Au}$ gust 2004. D uring this period all guardians of girls aged 4-9 years presenting to the emergency ward were asked for informed consent to participate in the study. 0 ut of 255 consecutive cases, who all agreed to take part in the general part of the study, 249 accepted full participation including inspection of the genitalia. All the patients constitute our study population, which was divided into cases with signs and symptoms of UTI and referents without such signs and symptoms.

Social and medical history were registered. The guardians, and the girl when appropriate, were asked about the FGM operation. Full examination, including inspection of genitalia, was performed on those who consented to it. Type and extent of genital operation, if present, were registered, as well as information on other health conditions.

\section{D iagnosis of U TI}

U rine culture indicating a significant amount of bacteria is the golden standard for diagnosing 
UTI. This was not possible to arrange in this study. We rather opted for UTI diagnosis based on dipsticks in combination with symptoms, which has shown satisfactory sensitivity and specificity for starting presumptive treatment in children. ${ }^{15,16}$ U rine was analysed by dipsticks (Multistix ${ }^{\circledR}$ 5, Bayer D iagnostics M fg., Ltd. Bridgend, UK ) for leucocytes (leucocyte esterase) and nitrite (product of $\mathrm{G}$ ram-negative bacteria). Diagnostic criteria for UTI were:

- positive nitrite test independent of symptoms, or

- + for leucocytes $(15 / \mu l)$ in combination with symptoms from the urinary tract, or

- ++ for leucocytes or more $(>70 / \mu \mathrm{l})$ irrespective of symptoms.

Axillary temperature was measured. In the presence of UTI criteria and fever more than $38.5^{\circ} \mathrm{C}$, the case was diagnosed as febrile UTI, assumed to be pyelonephritis in the absence of other explanations for the fever.

\section{Statistical A nalysis}

$D$ ifferences between cases and referents were analysed by calculating odds ratios (O R) with $95 \%$ confidence intervals $(\mathrm{Cl})$.

\section{E thical C onsiderations}

Thestudy is by its nature descriptive, and no more examinations were performed than would normally be the case. 0 ne can argue that inspection of the genitalia is usually not done, which might be true, but in severely ill children presenting to the emergency ward, inspection of genitalia should be part of the routine examination in this age group. 0 therwise important clinical findings might be missed. In this study, even patients with mild symptoms, which were not obviously related to the genitalia, were asked to participate. This was necessary since it is not known what kind of symptoms could be related to $F G M$. Symptoms from the genital tract would rather be under-reported, while symptoms from other parts of the body overemphasised. If the genitalia had not been inspected, this hidden morbidity could have been overlooked.

The guardians were thoroughly informed about the nature of the study, and they gave their informed consent. Specially trained female Sudanese medical doctors (AS, HB, SE, TI) did all clinical examinations and data collection. Examination, including inspection of the genitalia, took place in a calm and secluded room with no other person present than the parents and the physician on duty.

Patients who were not willing to participate in the study had the same procedures done as is usually the case at this hospital. Participating cases diagnosed as having UTI received free treatment. Before the onset of data collection the different studies were approved by ethics committees of the Children's E mergency H ospital, K hartoum, Sudan, and the K arolinska Institutet, Sweden.

\section{Findings}

0 ut of 255 girls who were enrolled for the study, the guardians of 249 girls accepted full examination including inspection of the genitalia. The median age was six years (range 4- 9 years). The most common complaints were fever $(62 \%)$, followed by cough (47\%), vomiting/ diarrhoea (22\%) and abdominal pain (19\%). Twelve girls (4.7\%) had complaints about the urogenital area, mainly burning micturition. No girl presented with immediate effects of recently performed FGM operation.

Fifty two girls (20\%) had undergone FGM. For a large share of the rest, there was an intention to do it, leaving 61 (24\%) allegedly without FG M in the future. $O$ ut of the 48 girls with $F G M$, on whom it was possible to inspect genitalia to verify the form of FGM, $13(27 \%)$ had WHO type I, three $(6.3 \%)$ had WHO type II and $32(66.7 \%)$ had WHO type III.

Altogether, 38 girls with FG M (73\%) were reported to have been bedridden for one week 
or more following the FG M operation. In spite of this, only five of the 52 girls with FG M (10\%) were said to have had immediate complications. $O$ ne of them had urine retention and fever, and the others had shock with unconsciousness, fever, wound infection and urine retention. All these five FGM operations were performed by midwives. The differences between those with and those without $F G M$, regarding previous history of symptoms from the genitalia ( $44 \%$ and $40 \%$ respectively) or previously having sought medical care for genital problems (21\% and $13 \%$ respectively), were not significant.

According to the diagnostic criteria, 20 out of 51 girls with FGM (39\%) and 61 out of 203 without FGM (30\%) were diagnosed as having UTI (difference not significant). O nly three had positive nitrite; the rest of the diagnoses relied on significant amounts of leucocytes and symptoms. A mong girls below seven years of age, however, those with FG M had a significantly higher risk of UTI than those without FG M , 20\% of UTI cases having FG M against only $4.5 \%$ of the others $(O \mathrm{R}=5.2 ; 95 \% \mathrm{Cl} 1.4,20.7)$. UTI was not over-represented among those who had undergone FG M during the last year, as compared to those who had it done earlier. G irls who were found by inspection to have a form of $F G M$ that narrowed the vulva had significantly more UTI, according to the criteria, than others (57\% and $30 \%$ respectively) $(0 \mathrm{R}=3.0 ; 95 \% \mathrm{Cl} 1.2$, 8.0). O nly five girls had febrile UTI/ pyelonephritis - two of 52 girls with FGM and three of 203 without FGM.

Most girls with UTI did not have current complaints from the urogenital tract. 0 nly $8 \%$ of those diagnosed as having UTI answered positively when asked about urinary tract symptoms. In comparison, 3\% of girls with other diagnoses reported such symptoms.

The possibility that UTI criteria have low specificity for UTI, leading to some false positive UTI diagnoses, made us test leucocytes in urine as an independent factor, disregarding the un- derlying cause. A mong girls with FG M , 25\% had significant leucocyturia (more than or equal to $++, 70 / \mu \mathrm{l})$ as compared to $21 \%$ among those without FGM (ns). N either form of FGM, age at operation, nor vulva narrowing showed any association with leucocyturia. G irls under seven years of age with FGM tended to have leucocyturia more frequently $(29 \%)$ than those without FG M (13\%), but the difference was not significant.

\section{Discussion}

This study shows a possible relationship between FGM and urinary tract infection. While several results indicate the existence of severe complications for the girl, it is also clear that the full extent of morbidity impact of FG M on the girlchild is not visible within the health care system.

Diagnosis of UTI is based on the presence of a significant amount of bacteria in the urine, and the most appropriate method for diagnosing this is by culture. For various logistical and practical reasons, it was not possible to organise this in the current setting. We, therefore, used dipsticks in combination with symptoms to diagnose UTI. There are, admittedly, disadvan-tages with this strategy. D iagnosing UTI in children by dipsticks positive for leucocyte esterase and/ or nitrite has shown high sensitivity and specificity ( $88 \%$ and $96 \%$ respectively) in a meta-analysis. ${ }^{15}$ The $2+$ for leucocyte esterase or positive nitrite has been suggested as a strategy for presumptive treatment of UTI in children. ${ }^{16}$ The high proportion diagnosed as having UTI in the present study implies an over-diagnosis of UTI and that these criteria do not work in the present clinical setting. There might be several reasons for this. 0 ther conditions such as schistosomiasis, which are endemic in Sudan, might also cause leucocyturia.

$G$ enital mutilation might cause environmental disturbances that possibly result in accumulation of leucocytes, and the anatomical changes brought about by the operation possibly prevent the free flow of urine and normal cleaning when the sides 
are stitched. This may explain why girls having undergone a form of FG M narrowing the vulva were more likely to be classified as having UTI. The results indicate that there might be an association between FGM and UTI, diagnosed by the stated criteria for girls below seven years. This possible association has to be interpreted bearing in mind the limitations of the methodology. I rrespective of where the leucocytes stem from - urinary bladder, urethra or vulva - their presence indicates a disruption of the normal state with, to some extent, inflammation.

Labial adhesions and urethral strictures are known predisposing factors for UTI in girls. U rethral strictures are rare, and usually result from trauma. The female urethra is well protected from accidental trauma during childhood, ${ }^{17}$ but iatrogenic trauma, for instance, during the FG M operation, might cause urethral stricture. Spontaneous labial adhesion is associated with local inflammation, and in the combination of the hypoestrogenic conditions of the pre-pubertal vulva, the condition might cause vulvo-vaginitis, ${ }^{18}$ asymptomatic bacteriuria ${ }^{19}$ and recurrent UTI. ${ }^{18,20}$ Theoretically, any form of FGM where the two sides heal together to any degree would besimilar to labial adhesions as risk factor for vulvovaginitis, asymptomatic bacteriuria and recurrent UTI. There have been case reports and descriptive studies indicating a relation between UTI and FG M , 5,21,22 but until now no systematic study on this possible association in girls. In adults, however, UTI has been shown to be significantly associated with FG M. A mong pregnant women, $22.9 \%$ of those with FGM had E . coli in their urine culture, compared to $4.6 \%$ among controls..$^{23}$ In a large unselected sample from Sudan 1962-1966 ( $\mathrm{n}=$ 4024), $28 \%$ of women with FG M type III had positive urine cultures, compared to $8 \%$ of those with FGM type I or without FGM. ${ }^{24}$

The anatomical changes due to FG $M$, leading to micturition problems, difficulties in emptying the bladder due to strictures or painful micturition, provide a plausible theoretical framework

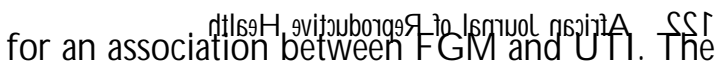
FGM operation could, however, also alter the local environment in the vulva, leading to increased risk of infections. In a study performed in K hartoum in 2004 we demonstrate a highly significant association between the anatomical extent of FGM and primary infertility. ${ }^{25}$ Laparoscopic post-inflammatory adnexal changes were not the only explanation for the strong association, since infertile cases without such adnexal pathology showed similar association. Thus, one can hypothesise that the FG M operation leads to other physiological or functional changes in the genitalia. This hidden pathology in the girl-child does not present clinically until the young woman is unable to conceive, which poses a challenge to both paediatricians and gynaecologists.

The complications for girls described in literature derive mainly from data reported by adult women. To the best of our knowledge there are only a few published studies carried out on girls. D escriptive hospital-based studies from $\mathrm{N}$ igeria found that the commonest presenting complications following genital mutilation in girls relate to micturition (dribbling incontinence, straining and retention of urine and urinary tract infections) ${ }^{22}$ and that unintentional labial fusion with sequalae is common. ${ }^{21} \mathrm{E}$ arly complications, such as haemorrhage, septicaemia and tetanus were encountered, but not to the degree the authors expected. ${ }^{21} \mathrm{~K}$ abira et al ${ }^{26}$ reported an unpublished study from $\mathrm{K}$ enya indicating that FG M contributes to high rates of school dropout for girls. $A$ study on the Somali Family H ealth Survey shows excess female child mortality in the age group 515 years, which is when FGM is performed. ${ }^{27}$ 0 ther factors than $F G M$, such as favouring sons when feeding and seeking medical care for children, could contribute to this excess mortality. The authors, however, also found that the more severe forms of FGM (assuming that daughters had the same form of FGM as their mother) had higher child mortality than less severe forms. 
In the present study we found no clinical signs of current direct complication of FGM, which may be due to the small sample size. However, there were also very few immediate complications reported. In clinical paediatric practice in Sudan, it is rare to see complications of FGM. There may be several reasons for this, for instance: (i) reluctance among mothers/ family members to seek paediatric/medical care in cases of immediate complications after FG $\mathrm{M}$; and (ii) nonrecognition of the entity of $F G M$ as genital trauma within the field of paediatrics.

The findings that only $8 \%$ of girls with UTI reported urogenital symptoms and that only $10 \%$ stated immediate complications related to the operation, in spite of the fact that $73 \%$ of the girls subjected to FGM had been bedridden for one week or more after the operation, imply that symptoms from this part of the body are under-reported. A previous study from Sudan had shown that only a small fraction of immediate complications were brought to medical attention..$^{28}$ The under-reporting of symptoms from the urogenital tract clearly shows the importance of asking specific questions relating to this area, routinely performing urinalysis, irrespective of complaints, and inspecting the genitalia on more liberal grounds. Even though genital inspection should be a part of the routine examination of paediatric patients, such inspection is, according to our observations, rarely done. This reluctance to ask about symptoms from the genital tract and to inspect the genitalia implies a failed diagnosis with inappropriate treatment, which in turn might increase the risk of further complications.

In conclusion, female genital mutilation contributes significantly to morbidity in childhood. A large share of this does not come to medical attention because symptoms are under-reported or not taken into account by the doctor. D ue to lack of scientific studies on how genital mutilation affects girls there is scant knowledge of which signs, symptoms and disease entities relate to
FG M, but awareness about this entity of genital trauma in girls needs to be raised among paediatricians and others working with children.

\section{Acknowledgements}

This study was funded by the Swedish International D evelopment A gency (Sida/ SARE C), the Regional Research Council of N ortheast Skåne, Sweden, and the D epartment of Paediatrics, Centralsjukhuset, K ristianstad, Sweden.

\section{References}

1. World $\mathrm{H}$ ealth $\mathrm{O}$ rganization. Female $\mathrm{G}$ enital $M$ utilation: A $n$ O verview. G eneva: World $H$ ealth O rganization, 1998.

2. Sudan D emographic and H ealth Survey 1989/ 1990: D epartment of Statistics, Ministry of E conomic and $\mathrm{N}$ ational Planning, $\mathrm{K}$ hartoum, Sudan. Institute for Resource D evelopment/ M acro International, Inc. Columbia, M aryland USA, 1991.

3. $E I D$ areer $A A$. E pidemiology of female circumcision in the Sudan. T rop D od 1983; 13(1): 41-45.

4. IsaAR, Shuib R and O thman M S. The practice of female circumcision among M uslims in K elantan, M alaysia. R eprod H ealth M atters 1999; 7(13): 137144.

5. A wang $N A$, V iegas $C$ and $V$ iegas $O A C$. Incomplete bladder emptying due to labial fusion in a pubertal girl: a delayed consequence of female circumcision. A ust N Z J 0 bstet $G$ ynaecol 2004; 44(4): 372-373.

6. Population Council. FemaleC ircumcision in Indonesia: E xtent, Implications and Possiblel nterventions to U phold W omen's H ealth R ights. Jakarta: Population Council, Indonesia, 2003.

7. WHO. Female Genital Mutilation: Report of a WHO Technical Working G roup, G eneva, 17-19 July 1995. G eneva: World H ealth O rganization, 1996.

8. O bermeyer $\mathrm{CM}$. Thehealth consequences of female circumcision: science, advocacy, and standards of evidence. M ed A nthropol Q 2003; 17(3): 394-412.

9. Yount K M and Balk D L. A demographic paradox: causes and consequences of female genital cutting in Africa. In: Segal M T, D emosV and K ronenfeld 
JJ ( $E$ ds.). A dvances in $G$ ender Research 8: $G$ ender Perspectives on Reproduction and Sexuality. O xford: Elsevier JAI, 2004; 199-249.

10. EI D areer A. Attitudes of Sudanese people to the practice of female circumcision. Int J E pidemiol 1983; 12(2): 138-144.

11. A Imroth $L, A$ Imroth-Berggren $V, H$ assanein $O M$, EI $\mathrm{H}$ adi $\mathrm{N}$, Al-Said SS, $\mathrm{H}$ asan SS, et al. A community based study on the change of practice of female genital mutilation in a Sudanese village. Int J $G$ ynaecol 0 bstet 2001; 74(2): 179-185.

12. A Imroth $L$, A Imroth-Berggren $V, H$ assanein $O M$, A I-Said SS, H asan SS, Lithell U B, et al. M ale complications of female genital mutilation. SocSa M ed 2001; 53(11): 1455-60.

13. G erais $A S$ and Bayoumi $A$. $F$ emale $G$ enital $M$ utilation ( $F$ GM) in the Sudan: A Community Based Study: K hartoum: K hartoum U niversity Press, 2001.

14. I slam M M and U ddin M M. Female circumcision in Sudan: future prospects and strategies for eradication. Inter F am Plann Persp 2001; 27(2): 71-76.

15. Gorelick MH and Shaw K N. Screening tests for urinary tract infection in children: a meta-analysis. Pediatrics 1999; 104(5): e54.

16. Shaw KN, MCG owan KL, Gorelick MH and Schwartz JS. Screening for urinary tract infection in infants in theemergency department: which test is best? Pediatrics 1998; 101(6): E 1.

17. N elson WE, Behrman RE, K liegman RM and Jenson H B. N elson's Textbook of Pediatrics. 16th edition. Philadelphia: Saunders, 2000, p. 1637.
18. $N$ elson WE, Behrman RE, $K$ liegman RM and Jenson HB. N elson's Textbook of Pediatrics. 16th edition. Philadelphia: Saunders, 2000, pp. 1660-01.

19. Leung AK and Robson WL. Labial fusion and asymptomatic bacteriuria. E ur J Pediatr 1993; 152(3): 250-251.

20. Podolsky M L. Labial fusion: a cause of recurrent urinary tract infections. Clin Pediatr (Phila) 1973; 12(6): 345-346.

21. E gwuatu VE and A gugua NE. Complications of female circumcision in N igerian I gbos. B r 0 bstet $G$ ynaecol 1981; 88(11): 1090-93.

22. A gugua NE and Egwuatu VE. Female circumcision: management of urinary complications. I T rop Pediatr 1982; 28(5): 248-52.

23. D esilva S. O bstetric sequelae of female circumcision. E ur J 0 bstet G ynecol Reprod Biol 1989; 32(3): 233-240.

24. Shandall A. Circumcision and infibulation of $\mathrm{fe}$ males. Sudan M ed J 1967; 5(4): 178-212.

25. Almroth $L$, Elmusharaf $S$, EI H adi $N, O$ beid $A$, EI Sheikh M A, E Ifadil SM and Bergstrom S. Primary infertility after genital mutilation in girlhood in Sudan: a case-control study. $L$ ancet 2005; 366:385-391.

26. K abiraWM , G achukiaE $W$ and Matiangi FO. The effect of women's role on health: the paradox. Inter J G ynecol O bstet 1997; 58(1): 23-34.

27. Mohamud $O A$. Female circumcision and child mortality in urban Somalia. $G$ enus 1991; 47(3-4): 203-223.

28. EID areer A. Complications of femalecircumcision in the Sudan. Trop D od 1983; 13(3): 131-133. 